\title{
Geographic Information System in Mapping Land Use in South Aceh District
}

\author{
Oktalia Triananda Lovita, ${ }^{1, *}$, Resky Rusnanda ${ }^{2}$ \\ ${ }^{a}$ South Aceh Polytechnic, Jl. Reklamasi Pantai, Tapaktuan and 23711, Indonesia \\ ${ }^{b}$ South Aceh Polytechnic, Jl. Reklamasi Pantai, Tapaktuan and 23711, Indonesia \\ I. Oktalia.t.lovita@gmail.com *; ${ }^{2}$ Officialreskyrusnanda@gmail.com \\ * Oktalia Triananda Lovita
}

\begin{tabular}{|c|c|}
\hline ARTICLE INFO & ABSTRACT \\
\hline $\begin{array}{l}\text { Article history: } \\
\text { Accepted }\end{array}$ & $\begin{array}{l}\text { The dawn of the age of computerization has opened up a new horizon and } \\
\text { paradigm in the decision making process and dissemination of information. In the } \\
\text { past difficulties arise when a large bulk of data representing of modeling a certain } \\
\text { phenomenon was to be compiled because these data were often detached from each } \\
\text { other. With Geographic Information System (GIS), the storing, administration, } \\
\text { processing, manipulation, analysis and exhibition of important data in a system of } \\
\text { information can be done with ease and speed. This study attempts to represent } \\
\text { and model the available data of Sourt Aceh Selatan concerning its administrative } \\
\text { boundaries, land, geology, land use and slope, Using ArcGIS 10.3, a GIS software } \\
\text { that is capable to represent spatial data as well as attributes of the study areas. the } \\
\text { results of rms error on landsat } 8 \text { oil images obtained mean } 0.51 \text {, GIS technology } \\
\text { in civil engineering work is normally used in the planning and preparation of a } \\
\text { new land for the development of a Land Use. }\end{array}$ \\
\hline
\end{tabular}

Keywords:

Geographic Information System,

Data, Landuse, ArcGIS,

Copyright $(C) 2018$ Politeknik Aceh Selatan. All rights reserved.

\section{Introduction}

South Aceh Regency is one of the Regencies in Aceh Province, Indonesia. The capital of South Aceh is Tapaktuan. Before standing alone as an autonomous district, candidates for the region of South Aceh Regency were part of the West Aceh Regency. The formation of the South Aceh Regency was marked by the enactment of Emergency Law Number 7 of 1956 on November 4, 1956. South Aceh Regency on April 10, 2002 was officially divided according to RI Law No. 4 of 2002 into three Regencies, namely Southwest Aceh District, Aceh Singkil District and South Aceh Regency.

The computerized era has opened up new insights and paradigms in the decision-making process and information dissemination. Data that represents the real world can be stored and processed in such a way that it can be presented in simpler forms and as needed. In accordance with the development of technology, especially graphic computers, databases, information technology, and sensory satellite technology (remote sensing), the need for storing, analyzing, and presenting complex structured data with large numbers is increasingly urgent. The first is the type of data that represents the spatial aspects of the phenomenon in question. This type of data is often referred to as position, coordinate, space, or spatial data. Whereas the second is the type of data that represents descriptive aspects of the phenomenon being modeled. Aspect This descriptive includes items or properties from the relevant phenomenon to the time dimension. This type of data is often referred to as attribute data or non-spatial data ${ }^{[4]}$.To be able to operate this system requires hardware and software. 


\section{The Proposed Method}

2.1 Geographic Information System (GIS)

According to the System ${ }^{[1]}$ is a set of interrelated and interconnected procedures to do a task together. Information is the result of processing data from one or various sources, which are then processed so as to provide value, meaning and benefits. In the process of processing data into information, the verification process is also accurate, specific and timely. Maintaining the Integrity of the Specifications.

\subsection{Analysis Functions}

The mapping unit must determine its value (score) so that it can be combined with other maps for analytical purposes. The ability of GIS can also be identified by the analysis functions that can be performed. In general there are two types of analysis functions in GIS which include the function of spatial analysis and attribute analysis functions (attribute database).

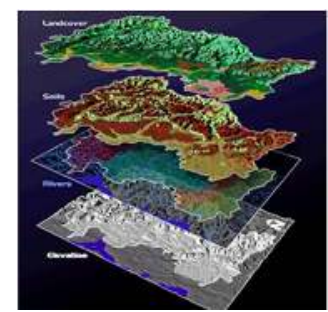

Fig 2.2 Description of layer stages in GIS

2.3 Citra Satelit Landsat-8

Landsat-8 was launched from Vandenberg Air Force Base in California on February 11, 2013, on an Atlas $\mathrm{V}$ rocket. The mission is to obtain high-quality data that meets both scientific and operational requirements of USGS and NASA to observe land use and land cover change. The Landsat-8 spacecraft, built by Orbital Sciences Corporation, has a 5-year mission life plan, including enough fuel for 10 years to operate. The core of the observation is Operational land imager (OLI), which was designed and built by Ball Aerospace and Technologies Corporation by collecting ground surface data with spatial resolution and consistency of spectral band specifications with Landsat historical data ${ }^{[4]}$.

Tabel 2.1 Specifications of LDCM Imaging Sensor Spectral Channels (Landsat-8) (required by NASA/USGS).

\begin{tabular}{|c|c|c|c|}
\hline 7 निया & 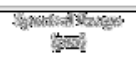 & Th & 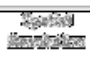 \\
\hline & 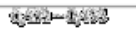 & 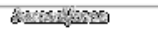 & \\
\hline 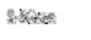 & 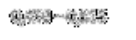 & 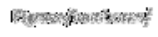 & antr \\
\hline 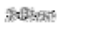 & refos-5y & prims & \\
\hline 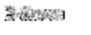 & 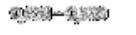 & 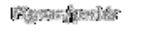 & \\
\hline 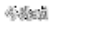 & 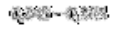 & 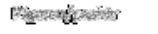 & 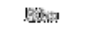 \\
\hline \multirow{2}{*}{ 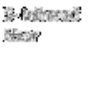 } & (1) & 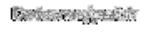 & \\
\hline & 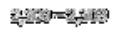 & 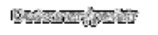 & \\
\hline ANebiax & 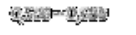 & 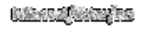 & \\
\hline 2wom & 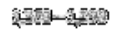 & Emingerang & \\
\hline $6 \sqrt{2} 20$ & 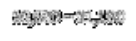 & Eovernas & Eng \\
\hline SWOAT & 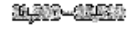 & and & Alon: \\
\hline 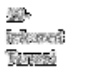 & whosyed & 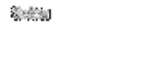 & assag \\
\hline 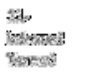 & tostem & 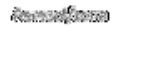 & 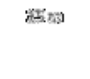 \\
\hline
\end{tabular}

Source : USGS,2013 


\section{Method}

This research is directed at creating a new land use map in the District of South Aceh which is made into a Geographic Information System (GIS), so that after this study users can find out information on new land use for office development. The stages in processing the data of this research can be seen in the figure below.

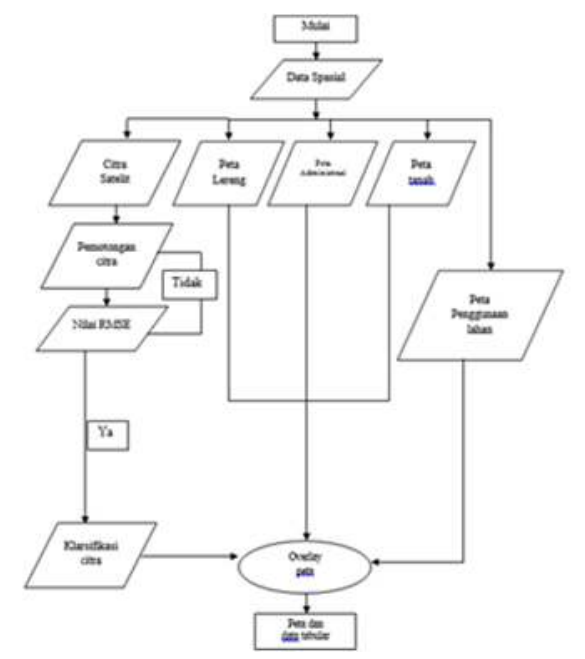

Figure 3.1 Flow Chart of Research Stages

The following is an explanation of the diagram of the processing steps of the research data:

1. Data Collection and Field Data Analysis

This data collection was carried out in order to obtain information on administrative boundaries, land boundaries and slope boundaries in the area of South Aceh.

2. Data Processing

a) RBI Map

The 1:250,000 scale Bakosurtanal map obtained was then scanned to get a map in the form of format.jpg. This process is done to get digital maps with format.dwg which is used as a base map for making geographic information systems.

b) Digitization process

Maps that have been rubbersheet then digitized to obtain digital maps. The digitized layers are the sub-district boundary layer, district boundary, local road, main road, other roads and paths, rivers and settlements. The results of digitization in the form of thematic maps include administrative boundary maps and transportation network maps. After that the maps are overlaid so that they form a whole and then editing in such a way as to be supplemented by spatial elements in the form of coordinate points of the field which eventually obtained the area land use maps Sourth Aceh.

c) Image Cutting.

The process of cropping aims to get digital images that only cover the research area so that data processing becomes more effective. The image cutting process is simply done by displaying an image based on the input of geographical coordinates that limit the research area.

f) Image Sharpening

This image sharpening is based on re-mapping the density level in an image after experiencing a change (transformation), and this form of transformation depends on the selected criteria. The scope of the operation to improve image quality is contrast enhancement, density pieces, increased edge sharpness, color enhancement, highlighting the main object. Image sharpening aims to improve image quality, which is to strengthen the contrast of features depicted in digital images. 


\section{Results and Discussion}

From some of the materials and tools used as well as the process carried out, results are obtained in the form of digital maps (softcopy) with tabular data and maps of hardcopy results of the layout printed with the printer or plotter, as well as printouts of administrative boundary map tables, land maps , land use map and slope map of South Aceh Regency. Hardcopy maps of the printed results, namely:

1. Administrative limit map of scale 1:750.000.

2. Map of Land scale 1: 750.000 .

3. Land Use Map scale of 1: 750.000 .

4. Slope Map scale of 1: 750.000.

\section{A. Geometric Correction}

In this study, geometric configuration is done with the aim of finding images that match the projection of the map by making GCP on the image. In the geometric measurement that is done is to determine the ground control point (GCP) using a map that has been done before, then do the transformation using the land control point. In an explicit process of 10 control points (GCP) which has an RMS error $<1$ pixel.

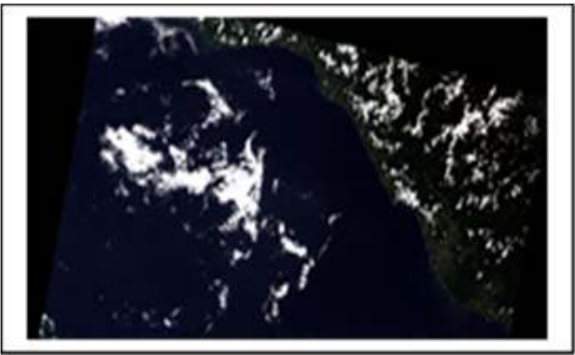

Fig 1. Bowtie satellite imagery correction results Landsat 8-OLI LC08_L1TP_130058_20180204_20180220_01_T1.

From these results it can be seen that the image before and after correction is different in position and shape, the purpose of correction bowtie is done to eliminate duplication of data on certain lines, especially those that are far from nadir.

\section{B. RMSE Accuracy Test Results}

From the geometric correction process that has been carried out for all fashion image data can be seen in the description below.

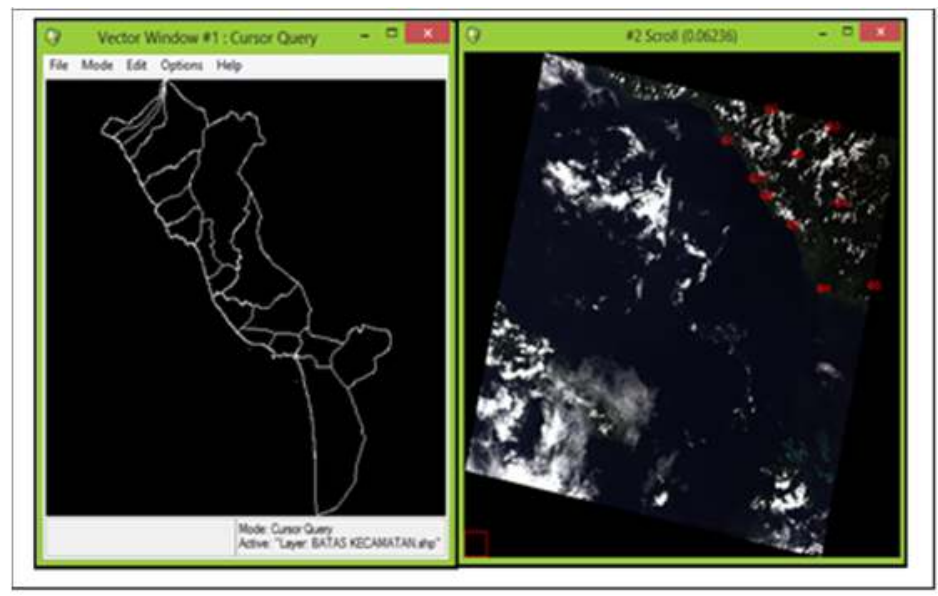

Fig 2. Ground Control Point results 
Table 1. RMS Results Error Satellite Imagery Landsat 8-OLI th 2018 (2/4/2018)

\begin{tabular}{|c|c|c|c|c|c|c|c|}
\hline \multirow{2}{*}{ Point } & \multicolumn{2}{|c|}{ GCP Map Point } & \multicolumn{2}{|c|}{$\begin{array}{c}\text { GCP Point LCB } \\
(2 / 4 / 2018)\end{array}$} & \multirow{2}{*}{$\begin{array}{c}\text { Erro X } \\
\text { (Pixel) }\end{array}$} & \multirow{2}{*}{$\begin{array}{c}\text { Error Y } \\
\text { (Pixel) }\end{array}$} & \multirow{2}{*}{$\begin{array}{c}\text { RMS } \\
\text { (Pixel) }\end{array}$} \\
\hline & X (Pixel) & Y (Pixel) & X (Pixel) & Y (Pixel) & & & \\
\hline 1 & 6995.50 & 4002.75 & 6995.50 & 4002.75 & 0.31 & 0.00 & 0.31 \\
\hline 2 & 7131.00 & 3363.00 & 7131.00 & 3363.00 & 0.54 & 0.00 & 0.54 \\
\hline 3 & 6504.00 & 2637.00 & 6504.00 & 2637.00 & 0.40 & 0.00 & 0.40 \\
\hline 4 & 6227.00 & 1812.00 & 6227.00 & 1812.00 & 0.62 & 0.00 & 0.62 \\
\hline 5 & 6367.00 & 1129.00 & 6367.00 & 1129.00 & 0.51 & 0.00 & 0.51 \\
\hline 6 & 5794.00 & 1086.00 & 5794.00 & 1086.00 & 0.79 & 0.00 & 0.79 \\
\hline 7 & 5272.00 & 844.00 & 5272.00 & 844.00 & 0.92 & 0.00 & 0.92 \\
\hline 8 & 4548.00 & 1354.00 & 4548.00 & 1354.00 & 0.41 & 0.00 & 0.41 \\
\hline 9 & 5415.00 & 2551.00 & 5415.00 & 2551.00 & 0.04 & 0.00 & 0.04 \\
\hline 10 & 5933.00 & 3267.00 & 5933.00 & 3267.00 & 0.18 & 0.00 & 0.18 \\
\hline \multicolumn{7}{|c|}{ Total RMS E } & 0.51 \\
\hline \multicolumn{7}{|c|}{ Rata-Rata RMS E } & 0.51 \\
\hline
\end{tabular}

From the results of geometric correction of satellite imagery Landsat 8-OLI Satellite Imagery obtained the average value of RMS Error for 2018 imagery of 0.51 . In processing geometric corrections are assumed to be true if the value of RMSerror is $\leq 1$ pixel where the value aims to reduce errors in the control point. If the value of RMS is $\geq 1$ pixel then that point must be corrected again. The RMSError results from the six Landsat 8-OLI satellite images used in the study have a value of $\leq 1$, so it can be concluded that the results have met the criteria of geometric correction. So that the image has become a geometrically corrected image.

\section{Clasification}

The characteristics of Landsat 8 OLI imagery can be seen in Table 1 . Band $1(0.435-0.451 \mu \mathrm{m})$ is a coastal / aerosol designed for monitoring coastal waters and aerosols closely related to band 2 , visible blue $(0.452-0.512 \mu \mathrm{m})$, therefore the band 1 not included in the classification process. Cirrus bands $(1,363-1,384 \mu \mathrm{m})$ are designed for identification of clouds and contain limited terrestrial surface information also removed from the classification process. Bands used in the classification process are 2, 3, 4, 5, 6 and 7 bands. Based on the results of visual interpretation and analyst knowledge about the characteristics of land cover distribution in South Aceh District, ten classes have been identified as the final type of land cover, namely land wake up, rice fields before harvest, new planting rice fields, shrubs, dense forest cover, medium cover forest, mixed forest, mixed gardens, open land and water bodies. Land cover data in the sample area is used as supporting data because it is closely related to the classification process and results. However, data collection in the sample area is an activity that requires a lot of time, effort, and costs. This study used a random sample based on areas known through the area of intersest (AOI). The tools in the Envi 5.1 software are supported by field data, land use maps, Google Earth maps and high resolution satellite imagery. Pixel distribution of sample area pixels is evenly distributed in areas in South Aceh District. Based on the results of the classification, the picture as below is obtained. 


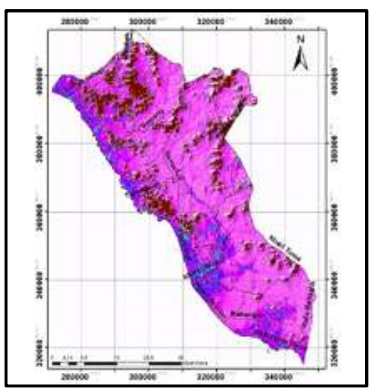

(a)

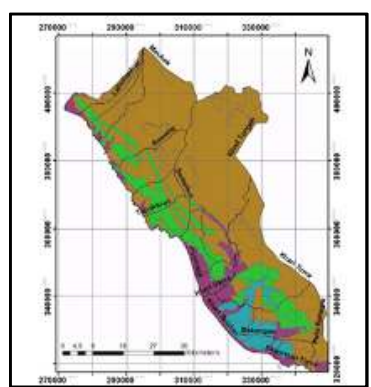

(b)

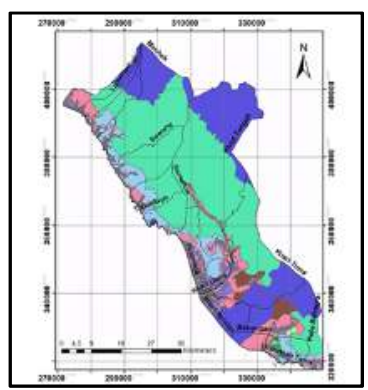

(c)

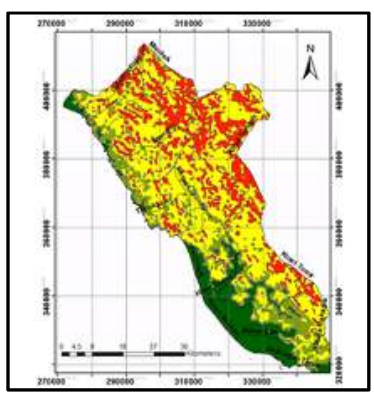

(d)

Fig 3. The classification results on Landsat 8-OLI satellite imagery on 2/4/2018 (a) Administration Map, (b) Map of Land Type, (c) Land Use Map, (d) Slope Slope Map.

This is easier than planning by using an analog map of each required data, and plotting the housing development plan one by one into these analog maps. This method requires a longer time compared to plotting / entering a housing development plan into a complete digital map with attribute data needed in planning.

\section{Conclusion}

The data input stage in this writing is done by inputting / displaying digital map data that has been obtained into ArcGIS 10.3 software, without going through digitization. The data processing stage in this writing is the overlay process, which results in a map resulting from overlaying with spatial data and the attribute data is a combination of the six overlayed maps. Data from digital maps obtained, as well as the results of the processes carried out are presented and stored in one project, which can be called / displayed and re-edited with ArcGIS software. The results obtained from the processes carried out are in the form of softcopy in the form of graphical data (digital maps) and attribute data (tables), while the hardcopy form is in the form of maps printed by the printer or plotter. The application of GIS in planning new land clearing in an area that will be used as housing by using digital maps with attribute data, will be easier than planning by using an analog map of each data needed to plan housing development.

\section{Acknowledgment}

Thank you to the Campus Engineering Sourth Aceh Polytechnic that has funded the sustainability of this journal.

\section{References}

[1] Agus Eka, Pratama. 2014. Sistem Informasi dan Implementasinya. Bandung: Informatika Bandung.

[2] Prahasta E. 2009. Sistem Informasi Geografis: Konsep-Konsep Dasar (Perspektif Geodesi \& Geomatika. Bandung: Informatika Bandung.

[3] Sitanggang, Gokmaria. (2010), Kajian Pemanfaatan Satelit Masa Depan : Sistem Penginderaan Jauh Satelit LDCM (Landsat - 8)b. Jakarta : Lembaga Penerbangan dan Antariksa Nasional (LAPAN), Berita Dirgantara Volume 11No. 2 Juni 2010: 47-58.

[4] USGS, (2013), Karakteristik Landsat-8, http:// landsat.usgs.gov/> acceess date 14 November 2015. 